\title{
Antibacterial Activity of 'Dahi' Prepared from Dairy Industry, Cottage and House Hold against Food Borne Pathogens
}

\author{
J.J. Patel ${ }^{1 *}$, Bency Antony Kathayat ${ }^{2}$ and K.T. Patel ${ }^{1}$ \\ ${ }^{1}$ Poultry Research Station, Anand Agricultural University, Anand, Gujarat, India \\ ${ }^{2}$ Food/Dairy Professional at Amul, Anand, India \\ *Corresponding author
}

\section{Keywords \\ Dahi, Lactic acid bacteria, Food pathogen, \\ Antibacterial activity, Zone of inhibition}

\section{Article Info}

Accepted: 16 December 2017 Available Online: 10 January 2018

\section{A B S T R A C T}

Dahi is highly palatable and easily digestible by human digestive system which contains macronutrients like protein, carbohydrates, fat and minerals like calcium and phosphorus. This study aims to screen the antibacterial activity of dahi which is good source of lactic acid bacteria (LAB). Lactic acid bacteria produce certain antimicrobial substance, which plays important role for the antibacterial activity for most of the milk products. The antagonistic properties of dahi against Staphylococcus aureus, Escherichia coli, Pseudomonas, Proteus vulgaris, Klebsiella were examined using agar well diffusion method. Thirty samples of dahi were collected from the Amul (A1 to A10), Local market (M1 to M10) and house hold level (H1 to H10). Industrial dahi (collected from AMUL) and Market dahi were collected from local area of the Anand city. However, the spectrum of inhibition was different for the different sources of dahi (Dracheva et al., 2007). All the samples of dahi exhibited the antibacterial activity against most of all the indicator pathogens. Amongst all the food borne pathogens Escherichia coli exhibited the highest antibacterial activity with a zone of Inhibition (ZOI) ranging from 18 to $21 \mathrm{~mm}$. Industrial dahi showed the higher antibacterial activity against all the food borne pathogens and least antibacterial activity for Klebsiella $(11 \pm 1 \mathrm{~mm})$. Dahi collected from Market showed higher antimicrobial property against Proteus vulgaris $(20 \pm 2.0 \mathrm{~mm})$ and least against Staphylococcus aureus. Whereas dahi collected from house showed inhibition of Pseudomonas $(21 \pm 1.5 \mathrm{~mm})$ and least for Staphylococcus aureus like market dahi. All dahi showed the remarkable inhibitory effect against both Gram positive and Gram negative pathogenic strains.

\section{Introduction}

Food is the matter of health and matter of trust also. Nowadays, food is no longer considered by consumers only in terms of taste and immediate nutritional needs, but also in terms of their ability to provide specific health benefits beyond their basic nutritional value. Currently, the largest segment of the functional food market is dominated by healthy food products targeted towards improving the balance and activity of the intestinal micro flora. A probiotic is a "live microbial food ingredients that, when ingested in sufficient quantities, exerts health benefits on the consumer"(Doron et al., 2006.). In general, it is believed that probiotics help to keep the balance between harmful and 
beneficial bacteria in the gut thus maintaining a healthy digestive system. Noteworthy, there are a large number of probiotic foods which date back to ancient times which are mostly originated from fermented foods as well as cultured milk products. (Astha et al., 2012)

Probiotic strains compete with other infectious bacteria for nutrients and cell-surface and helps toward them off by inhibiting their colonization. A few strains are also known to produce active enzymes which inhibit other pathogenic bacteria. The health benefits of probiotics have always been investigated with regard to their capability to sustain their availability, viability, digestibility and rendering of their health benefits to the host without altering the safety and the organoleptic properties of the food in which they have been incorporated. Today, viable probiotic strains with beneficial functional properties are available in the market as components of foods and beverages, in fermented dairy products like yogurt or as probiotic fortified foods as well as food preservatives.

As the change in taste of common people, milk is converted to many fermented products like Kefir, Dahi, Cheese, Butter milk, Cream. Dahi is highly palatable and easily digestible by human digestive system which contains macronutrients like protein, carbohydrates, fat and minerals like calcium and phosphorus (Sivakumar et al., 2010). Among the various fermented milk products, international market of dahi has improved remarkably because of its high nutritional value and therapeutically benefits (Murugan et al., 2013). Lactic acid bacteria, particularly those belonging to beneficial and non-pathogenic genera (Lactobacillus, Lactococcus, Streptococcus, Pediococcus and Leuconostoc) are widely used in food industry. Among lactic acid bacteria; Lactobacilli are the most important group and are gaining increasing attention in food fermentation industry because of their potential biotechnological interest. Lactic acid bacteria have attained significant importance in the dairy industry for their widespread use in the production of fermented foods (Farn et $a l .$, 2005). This organism prevents the growth of pathogenic bacteria in different ecosystems by production of antimicrobial substance such as organic acids, hydrogen peroxide and bacteriocins. (Gopal et al., 2001) The bacteriocin producing Lactobacillus may be used as protective culture to improve the microbial safety of foods (Olasupo et al., 1997)

\section{Materials and Methods}

\section{Collection of Dahi samples}

Dahi samples were collected from the Amul (Amul masti Dahi), local market area of Anand city and from the household level.

\section{Test organisms}

The tested pathogens used were Staphylococcus aureus, Escherichia coli, Pseudomonas, Proteus vulgaris, Klebsiella. All the cultures were maintained with regular transfer on $\mathrm{N}$ agar or $\mathrm{N}$ broth and stored in refrigerator at $4^{\circ} \mathrm{C}$.

\section{Media and reagents}

The nutrient agar (NA) was used for the antimicrobial assay. The reagents, indicator, carbon substrates for biochemical tests etc. used in the study were of analytical grade and procured from Hi Media Chemicals Ltd., Mumbai, India.

\section{Detection of antimicrobial activity by agar well diffusion method}

An agar well diffusion method as described by Klaenhammer was used with some 
modifications. An overnight culture of pathogens including Staphylococcus aureus, Escherichia coli, Pseudomonas, Proteus vulgaris and Klebsiella were grown in their selective medium.

Work area was cleaned and sterilized it with $70 \%$ iso-propanol. The contents of the culture of all organisms were swirled until it was equally murky throughout. Sterile cotton swab and glass rod was used to create a lawn, or carpet, of single organism on $\mathrm{N}$ agar plate. A lawn of an indicator strain was made by spreading the cell suspension over the surface of $\mathrm{N}$ agar plates. The mouth of the test tube was flamed before and after dipping the sterile swab into it. Labelling was done at the bottom of the petri dish with name, the date, name of organism. The plates were allowed to dry and a sterile cork borer of diameter $7.0 \mathrm{~mm}$ was used to cut uniform wells in the agar plates. Para film was wrapped around all plates and lids were placed on it. The plates were allowed to incubate for $24 \mathrm{hrs}$ in incubator at $37^{\circ} \mathrm{C}$. After $24 \mathrm{hrs}$ in the incubator; the presence of antibacterial activity was checked. This was done by looking for a clear area, called zone of inhibition (ZOI), surrounding a cup. To determine the affectivity of an antibiotic, diameter of the zone of inhibition around each disk was measured. Keeping the lid of the plate in place, using a ruler to measuring the diameter of the clear area in millimetres. After recording the average class data for the diameters of the zones of inhibition, The SIR (Susceptible, Intermediate and Resistant) table was used to determine whether each bacteria is susceptible (sensitive), unaffected (resistant) or somewhere in between (intermediate) for each of the antibiotics.

\section{Results and Discussion}

Comparatively, by physical and chemical observations all the three different sources of dahi differ in their colour, smell, texture etc. resulted as per the report of Malarkannan, et al., 2017. Preparation of dahi from the standardized or unstandardized milk leads to much variation in the total solids content of market dahi samples (Sarkar et al., 1996).

The data consisted of zone of inhibition (in $\mathrm{mm}$ ) for each samples of $d a h i$, per bacterial species. By comparing the antibacterial activity of bacterial species, a useful measurement was found to account for this disparity in data and zone of inhibition was measured for each sample. On the basis of results obtained, as shown in Table 1.

Amul dahi was found to be highly effective against all pathogens except Klebsiella. E.coli was highly sensitive to any of the fermented milk product like Curd, Cheese, butter etc. (Arokiyamary and Sivakumar, 2011) However E.Coli and Proteus vulgaris exhibited the highest antibacterial activity with zone of inhibition ranging from 19 to $21 \mathrm{~mm}$ respectively which were similar to the result of Mahnaz Kazemipoor et al., (2012) and also reported that Lactobacillus animalis (MF6) which exhibited the highest antibacterial activity against $E$. coli with Zone of inhibition of (20 \pm 1.3$)$. Whereas Staphylococcus aureus and Pseudomonas were showing the susceptibility with ZOI ranging from $15 \pm 1.5$ $\mathrm{mm}$ and $17 \pm 1.5 \mathrm{~mm}$ respectively.

As shown in Table 2, Market dahi exhibited highest antibacterial activity against E.Coli with Zone of inhibition ranging from 16.5 to $20.00 \mathrm{~mm}$ like Amul dahi but Market dahi had comparatively least antimicrobial activity against Staphylococcus aureus unlike Amul dahi. Mahnaz Kazemipoor et al., (2012) also found that Lactobacillus reuteri, isolated MF15 showed greater activity against E. coli $\left(\begin{array}{llll}12 & \pm & 0.8 & \mathrm{~mm}\end{array}\right)$ and least against Staphylococcus aureus $(8 \pm 1.7 \mathrm{~mm})$. It was determined that less susceptible pathogenic 
bacteria to market dahi were $S$. aureus and Klebsiella While similar results have been obtained from previous study of antibacterial activity of kefir on 7 bacterial species and 1 fungus was examined with disc diffusion method and it has been reported that $S$. Aureus was less sensitive pathogens and
Pseudomonas and E. coli were the least sensitive (Rodrigues et al., 2005). Sample from (M1 to M9) also exhibited the higher antibacterial activity against $P$ seudomonas and Proteus vulgaris with Zone of inhibition of 18 to $20 \mathrm{~mm}$ and Klebsiella giving the intermediate result around $14 \mathrm{~mm}$.

Table.1 Zone of inhibition in (mm) of samples Amul masti Dahi

\begin{tabular}{|c|c|c|c|c|c|}
\hline Sr. No. & Escherichia coli & Staphylococcus aureus & Pseudomonas & Proteus vulgaris & Klebsiella \\
\hline A1 & 21 & 15 & 17 & 20 & 12 \\
\hline A2 & 19 & 15.5 & 18 & 18.5 & ND \\
\hline A3 & 20 & 15 & 18 & 18 & ND \\
\hline A4 & 21 & 16 & 18.5 & 18.5 & 11.5 \\
\hline A5 & 20 & ND & 17.5 & 19.5 & 12 \\
\hline A6 & 20 & 16.5 & 17 & 20 & ND \\
\hline A7 & 20.5 & 16 & 18.5 & 19 & ND \\
\hline A8 & 21 & 15.5 & 18 & 20 & ND \\
\hline A9 & 20.5 & 16 & 17.5 & 18.5 & 11 \\
\hline A10 & 20 & ND & 18 & 18 & ND \\
\hline
\end{tabular}

Table.2 Zone of inhibition in (mm) of samples Market Dahi

\begin{tabular}{|c|c|c|c|c|c|}
\hline Sr. No. & Escherichia coli & Staphylococcus aureus & Pseudomons & Proteus vulgaris & Klebsiella \\
\hline M1 & 20 & 19 & 18 & 18.5 & 14 \\
\hline M2 & 17.5 & ND & 19.5 & 18 & 17 \\
\hline M3 & 16.5 & ND & 18.5 & 18 & 14.5 \\
\hline M4 & 20 & 18 & 20 & 18.5 & 18 \\
\hline M5 & 17.5 & 18.5 & 19 & 20 & 14 \\
\hline M6 & 19 & ND & 19.5 & 19 & 14.5 \\
\hline M7 & 18 & ND & 18.5 & 19.5 & 17.5 \\
\hline M8 & 18.5 & ND & 20 & 18 & 14.5 \\
\hline M9 & 17 & ND & 19.5 & 19 & 14 \\
\hline M10 & 17.5 & ND & 19 & 18.5 & 17 \\
\hline
\end{tabular}

Table.3 Zone of inhibition in (mm) of samples House Dahi

\begin{tabular}{|c|c|c|c|c|c|}
\hline Sr. No. & Escherichia coli & Staphylococcus aureus & Pseudomons & Proteus vulgaris & Klebsiella \\
\hline H1 & 20 & 19 & 21 & 18 & 18 \\
\hline H2 & 21 & 20 & 20.5 & 19 & 20 \\
\hline H3 & 20.5 & 20.5 & 21 & 18.5 & 18.5 \\
\hline H4 & 20 & ND & 20 & ND & 19 \\
\hline H5 & 19.5 & 18 & 21 & 18.5 & 19.5 \\
\hline H6 & 20 & ND & 20.5 & 19 & 20 \\
\hline H7 & 19 & ND & 20 & 18 & 19 \\
\hline H8 & 19.5 & 18 & 19.5 & 18 & 18.5 \\
\hline H9 & 19.5 & 18.5 & 20 & 19.5 & 18 \\
\hline H10 & 19 & 19 & 19.5 & 18.5 & ND \\
\hline
\end{tabular}

Determination of zone of inhibition, Resistant: 10 or less, Intermediate: 11-15, Susceptible: 16 or more 


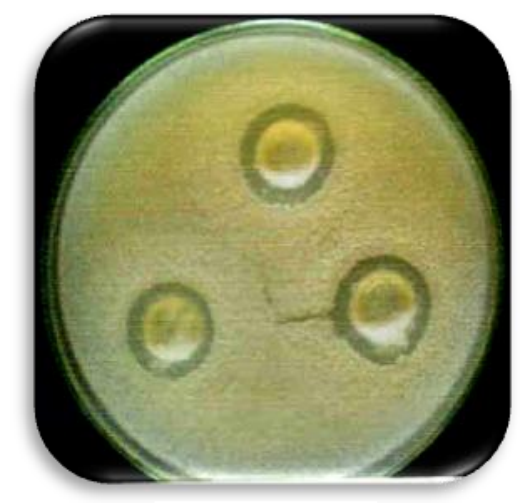

Figure. A

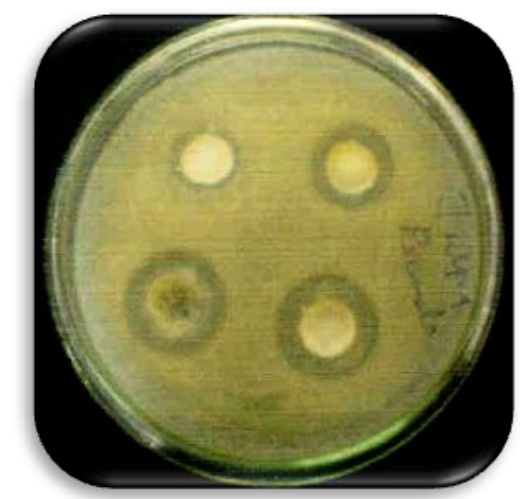

Figure. B

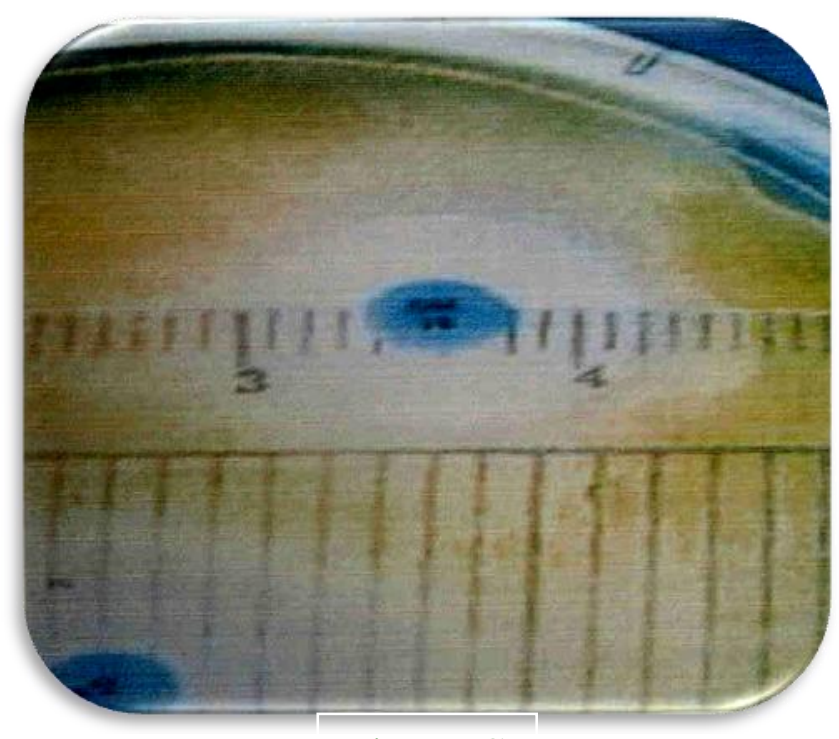

Figure. C

Figure. A: Petri Plate with a Lawn of an Indicator Pathogenic Strain of E.Coli and a Zone of Inhibition around the Well Containing the industrial, cottage and household Dahi.

Figure. B: Petri Plate with a Lawn of an Indicator Pathogenic Strain of Pseudomonas and a Zone of Inhibition. Figure. C: Shows the measurement of clear area (Zone of inhibition) in $\mathrm{mm}$.

As shown in Table 3, all the samples of house hold level (H1 to H10) exhibited antibacterial activity against all pathogens. E. coli, Staphylococcus aureus and Pseudomonas was more sensitive to home-made dahi showing Zone of inhibition of 19 to $21 \mathrm{~mm}$. Whereas Proteus vulgaris and Klebsiella exhibited the antibacterial activity with ZOI ranging from 18 to $20 \mathrm{~mm}$. Whatever the source of dahi, all the samples were more or less antagonistic against both gram positive (Staphylococcus aureus) as well as gram negative (Escherichia coli) pathogenic bacteria which is supported by Mahnaz Kazemipoor et al., (2012).

Kotz et al., (1990) reported that yoghurt filtrate has in vitro antibacterial effect against three different E. coli strains. In this study, when inhibition zones are compared, typically, homemade yoghurt resulted in larger inhibition zones than commercial yoghurt. This may be because of making yoghurt using different strains and contamination of homemade yoghurt with different lactic acid bacteria during yoghurt making. As a result, the antibacterial effects 
of dahi from different source fermented dairy products against common food borne pathogens showed different results according to depending on the type of fermented dairy product used, species of pathogen bacteria and time.

In case of Staphylococcus aureus and Escherichia coli there were no significant differences observed in all the three sources of the sample of dahi. The results of present study were in line with the earlier findings of Aslim et al., (2005), that all the Samples obtained from Turkish dairy products have antimicrobials activity against Staphylococcus aureus and Escherichia coli. Amongst all, dahi is rich with microbial load, the results of this study were in line with the earlier findings of Riadh (2005). They reported a high incidence of microbial load in Curd (dahi) sample, when compared with other dairy products like Milk peda and cheese. It is however difficult to comment on the reason for this variability in the antimicrobial property amongst all the different sources of dahi since each one has different procedure of preparation.

In conclusion, the results obtained from study demonstrated the remarkable antimicrobial attributes of the dahi prepared from different fermented product of milk. The highest antibacterial effect against food borne pathogens used in this study was seen in different sources of dahi. A large number of lactic acid bacteria present in food products with different bioactive potentials especially in the form of antimicrobial properties have been identified from a variety of dairy products and also from a variety of plant sources mostly in the form of fermented and pickled vegetables. These scientific evidences have been a motivating factor to choose a dairy based fermented product, which could further confirm the results of this study, On the other hand, such positive outcomes would be a leading point towards application of simple worthy traditional methods such as fermentation.

For good health of all consumers, strict and preventive measure should be adopted to ensure contamination free milk products. Good hygienic, sanitary condition, good manufacturing practise and good storage condition will reduce the risk of poor microbiological quality and increase the safety of the product. It is suggested that the probiotic bacteria or/and metabolites in food can be used as an antibacterial agent against to food borne pathogens alone or in various combinations.

\section{References}

Arokiyamary, A., and Sivakumar, P.K., 2011. Antibacterial activity of Bacterocin producing Lactobacillus sp., isolated from traditional milk products. Current Botany, Volume 2: 05-08.

Aslim, B., Z.N. Yuksekdag and E. Sarikaya, 2005. Determination of the bacteriocinlike substances produced by some lactic acid bacteria isolated from Turkish dairy products. LWT-food science and technology, Vol.38 Issue 6, Page no. 691-694.

Astha Nigam, Avnish Kumar, Madhusudan H.V., and Neelam Bhola, 2012. In-vitro screening of antibacterial activity of lactic acid bacteria against common enteric pathogens. Journal of Biomedical Sciences Vol. 1 Page no. 16

Doron, S. and Gorbach, S.L., 2006. Probiotics: their role in the treatment and prevention of disease. Expert Review Anti-Infect. Ther, 4: Page no. 261-275.

Dracheva, L.V, Kudryasheva, A.A, and D. L. Ya., 2007.Antioxidant properties of probiotics. Molochnaya- 
Promyshlennost., Page no. 62-63.

Farn warth, E.R. 2005. Kefir a complex probiotic. J. Nutraceuticles, Functional and Medical Foods, Vol 4: Page no. 93117

Gopal, P.K, Prasad, J., Smart, J., Gill, H.S., 2001. In vitro adherence properties of Lactobacillus rhamnosus DR20 and Bifidobacterium lactis DR10 strains and their antagonistic activity against an enterotoxigenic Escherichia coli. International Journal of Food Microbiology.67 Page no. 207-216

Kotz, C.M., L.R. Peterson, J.A. Moody, D.A. Savaiano and M.D. Levitt, 1990. In vitro antibacterial effect of yogurt on Escherichia coli. Dig. Dis. Sci., 35: Page no. 630-637.

Mahnaz Kazemipoor, Che Wan Jasimah, Mohamed Radzi, Khyrunnisa Begum, Iman Yaze 2012. Screening of antibacterial activity of lactic acid bacteria isolated from fermented vegetables against food borne pathogens. Archives des sciences Vol.65, Issue 6.

Malarkannan. S.P, Ramesh. R, Kathirchelvan. M., 2017. Study on the microbial quality of dahi from retail outlets in Madurai, International Journal of Applied and Pure Science and Agriculture Vol.3. Issue 2.

Murugan, M., Suganya, K., and Murugan, T. 2013. Isolation and Characterization of probiotic lactic acid bacteria from milk and curd samples. International Journal of Pharma and Bio Science 4(1): Page no. $317-324$

Olasupo, N.A., Olukoya, D.K., Odunfa, S.A. 1997. Assessment of a bacteriocin-producing Lactobacillus strain in the control of spoilage of a cereal-based African fermented food. Folia microbiologica, 42(1) Page no. 31-34.

Riadh, AL-Tahiri, 2005. A comparison on microbiol conditions between traditional dairy produced sold in Kerala and same products produced by modern dairies. Pakistan Journal of nutrition, 4(5): Page no. 345-348.

Rodrigues, K., C.L. Gaudino, J.T. Carvalho, J. Evangelista and J.M. Schneedorf, 2005. Antimicrobial and healing activity of kefir and kefiran extract. International journal of Antimicrobial. Agents, 25: Page no. 404-408.

Sarkar, S.R., K. Kulia and A.K. Misra, 1996. Organoleptic, microbiological and chemical quality of misti Dahi sold in different district of West Bengal. Indian Journal of Dairy Science, 49: Page no. 54-61.

Sivakumar, N and Kalaiarasu, S. 2010. Microbiological approach of curd samples collected from different locations of Tamilnadu, India. International Journal of Current Research Vol.2 (10), Page no. 027-030.

\section{How to cite this article:}

Patel, J.J., Bency Antony Kathayat and Patel, K.T. 2018. Antibacterial Activity of 'Dahi' Prepared from Dairy Industry, Cottage and House Hold against Food Borne Pathogens. Int.J.Curr.Microbiol.App.Sci. 7(01): 2173-2179. doi: https://doi.org/10.20546/ijcmas.2018.701.261 